DOI: $10.23858 / S A 70.2018 .003$

\title{
Nadezhda Kotova*
}

\section{REVISITING THE NEOLITHIC CHRONOLOGY OF THE DNIEPER STEPPE REGION WITH CONSIDERATION OF A RESERVOIR EFFECT FOR HUMAN SKELETAL MATERIAL}

\begin{abstract}
Kotova N. 2018. Revisiting the Neolithic chronology of the Dnieper steppe region with consideration of a reservoir effect for human skeletal material. Sprawozdania Archeologiczne 70, 47-66.

Comparison of radiocarbon dates for human and animal bones from Neolithic cemeteries of the Dnieper region has demonstrated the necessity of using only the non-human material for determining the ages of these sites. This approach has made significant corrections to the dating of the Neolithic cultures in the Ukrainian steppe from the late $6^{\text {th }}$ to the early $5^{\text {th }}$ millennia calBC. The revision of the chronological position of some Surskoy Culture cemeteries (Vovnigi 3, Vovnigi 1, the first stage of Vilnyanka, the first and second stages of Yasinovatka 1) has resulted in more precise dates than previous estimates (about 5350-4950 calBC), and the latest date of occupation of the Surskoy Culture at sites in this region has likewise been revised to about $4900-4800$ calBC. According the correction, period $1 \mathrm{~b}$ of the Azov-Dnieper Culture is dated at about 5750-4900 calBC. The second peraiod of the Azov-Dnieper Culture should be dated around 4900-4700 calBC.
\end{abstract}

Keywords: Neolithic cemeteries, the Surskoy Culture, the Azov-Dnieper Culture, Dnieper rapids, radiocarbon chronology, reservoir effect for human bones

Received: 16.03.2018; Revised: 22.05.2018; Accepted: 21.09.2018

* Institute of Archaeology of the National Academy of Sciences of Ukraine, Gieroiv Stalingrada 12, Kyiv, Ukraine; nadja.kotova@hotmail.com 


\section{STATE OF THE PROBLEM}

The Surskoy and Azov-Dnieper Neolithic Cultures of the Dnieper steppe region are represented by materials from settlements and cemeteries. The age of the sites was determined on the basis of radiocarbon dates of the bones of animals from settlements and human bones from numerous cemeteries (Telegin et al. 2003; Kotova 2003). However, in recent years, many studies have considered the diets of individuals at Neolithic cemeteries in the Dnieper region and the resulting reservoir effect based on foods consumed (Lillie et al. 2009; 2011; 2016). These studies have shown that the dating of these cemeteries must take into account this reservoir effect, which is associated with the important role of freshwater resources in the Neolithic diet of the Dnieper valley.

The cultural attribution of burials, linking specific cemeteries to a particular group of settlements for which various economic activities are recorded, is also important and debated. Some authors consider all Neolithic burials in the area to belong to the DnieperDonets Culture (Telegin and Potekhina 1987; Lillie et al. 2009; 2016), whereas I divide them into two cultures: the Surskoy and Azov-Dnieper Cultures (Kotova 2003; 2010). Their burials differ in the orientation of the skeletons, the grave goods and ornaments of funerary clothes. The Azovo-Dnieper skeletons lie with their heads to the West and to the East (Mamaj Gora, Nikolskoye, Lysaya Gora, the large pit of Yasinovatka 1, Vovnigi 2, Vasilievka 5 cemeteries). Sacrificial places with stones and fireplaces on the surface were typical for this group. Sacrificial sites included concentrations of broken vessels in the latest Azov-Dnieper cemeteries (Kotova 2003).

In the cemeteries of the Surskoy Culture, the skeletons were oriented to the North and to the South (Vovnigi 1, Vilnyanka, individual burials of Yasinovatka 1, Sobachki, Chapli). There are no sacrificial places or stones on their surfaces. Adornments from the canine of the wild boar, stone and bone beads, stone axes, and wide flint blades inherent in AzovDnieper cemeteries are absent in the Surskoy grave goods.

At present, in each of the Neolithic cultures of the Dnieper steppe region, three chronological groups of sites are distinguished (Fig. 1; 2). Surskoy islands 1 and 2, Kodachok and Vinogradny belong to the oldest Surskoy sites in the Dnieper valley (Kotova 2010). Radiocarbon dates from the bones of animals at the Surskoy island 2 site give an age of about 6200-6000 calBC.

The second period of the Surskoy Culture consists of sites with ceramics, which display influences from the first period of the Azov-Dnieper Culture (a collar or an oblique cut in the rim, a combed zigzag, bands filled with combed imprints). These sites include: the lower layer of Strilcha Skelya, Igren-Gorodok, Kizlevy 5, Vovchok, Pohily, and Semenovka 2 (Kotova 2010). A few radiocarbon dates have been obtained, which give a date of about 5900-5350 calBC.

The Vovnigi right- and left-bank sites belong to the third period, as well as Vovnigi 3, Vilnyanka and the old part of the Yasinovatka 1 cemeteries (Kotova 2010). These monuments 

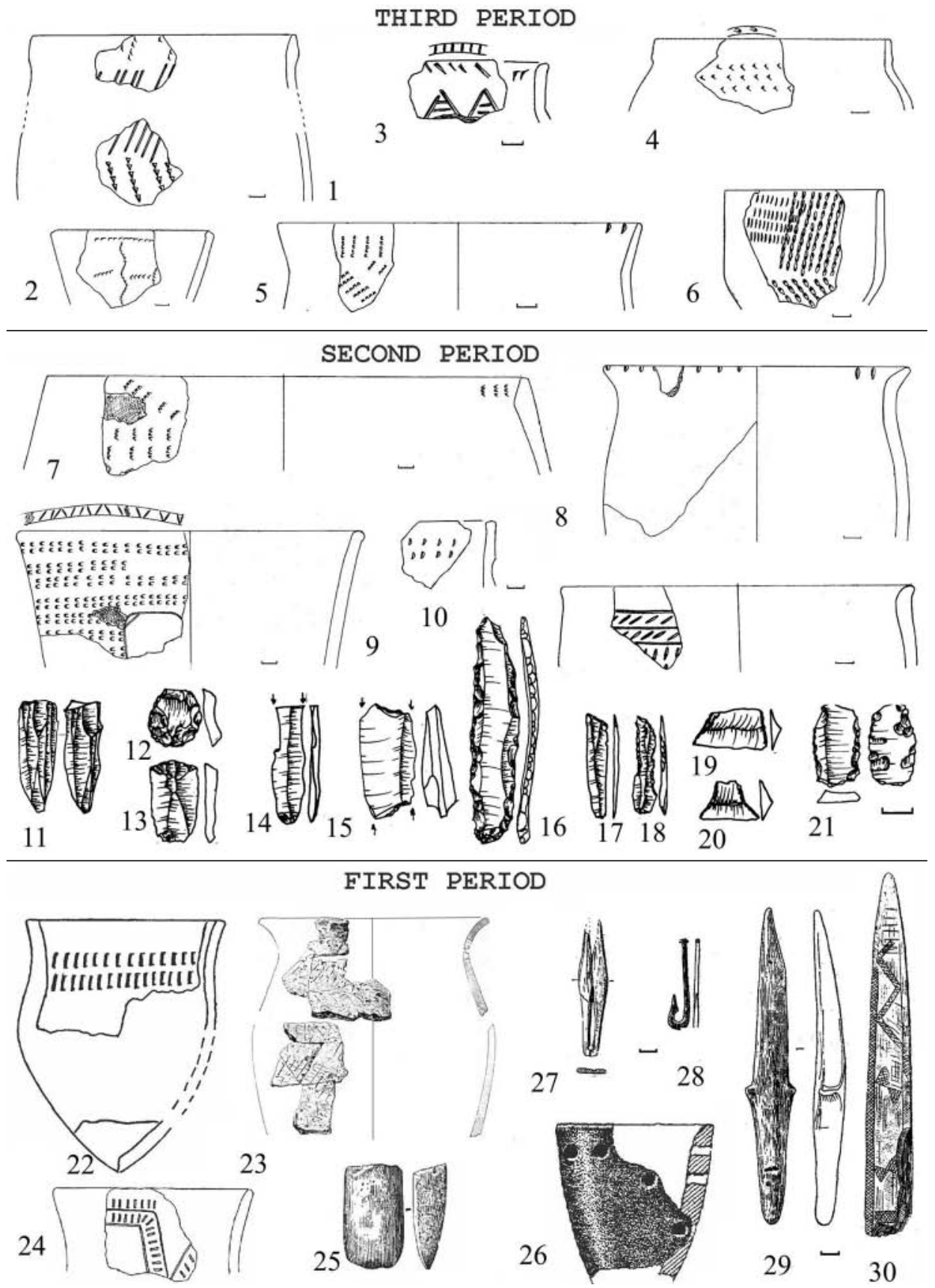

Fig.1. Materials of the Surskoy Culture: 1 - 4 - Vovnigi right-bank site; 5 - Vovnigi left-bank site; 6 - Pohily; 7-21 - Kizlevy 5; 22, 26 - Vinogradny; 23, 25, 27, 30 - Surskoy Island 1; 24 - Kodachok; 28, 29 - Surskoy Island 2 


\section{SECOND PERIOD}
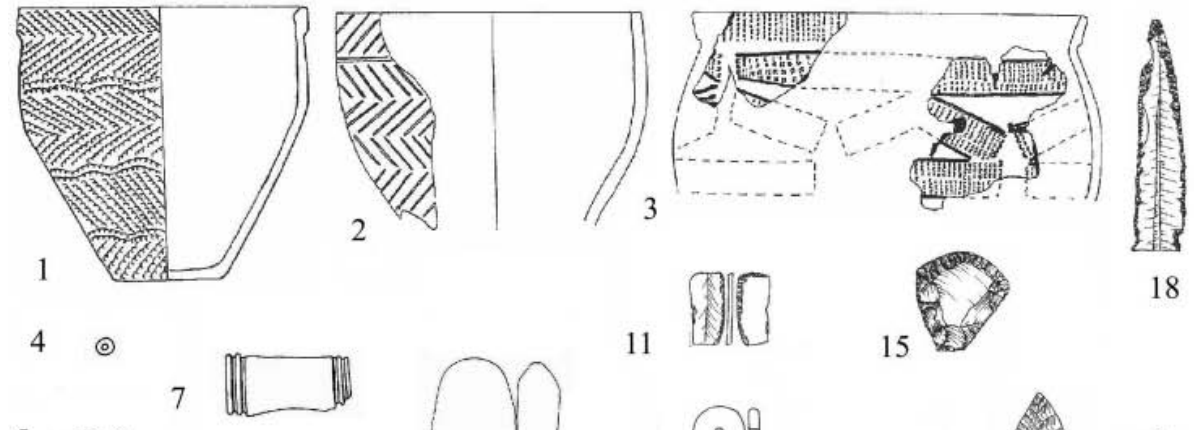

$5 \bigcirc 0$

8
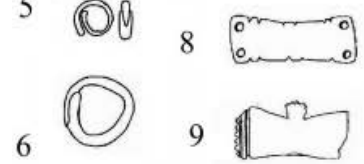

9
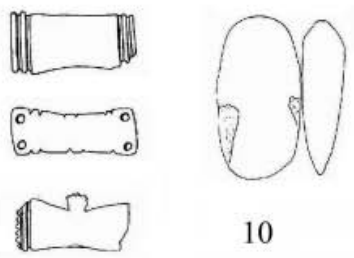

11

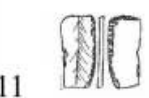

15

10

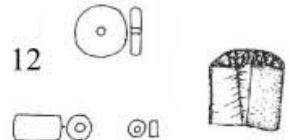

13

$\begin{array}{lll}14 & 16 & 17\end{array}$
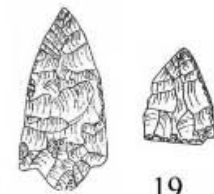

19

1B

FIRST PERIOD

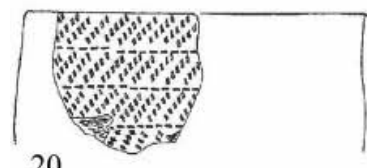

20
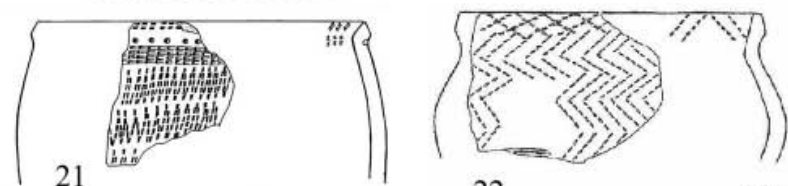

21

22

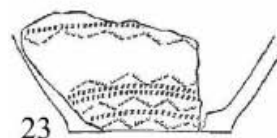

${ }_{24}$

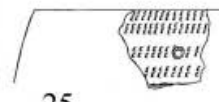

25

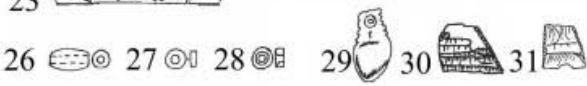

${ }_{32} \rightarrow$ 33

\section{$1 \mathrm{~A}$}
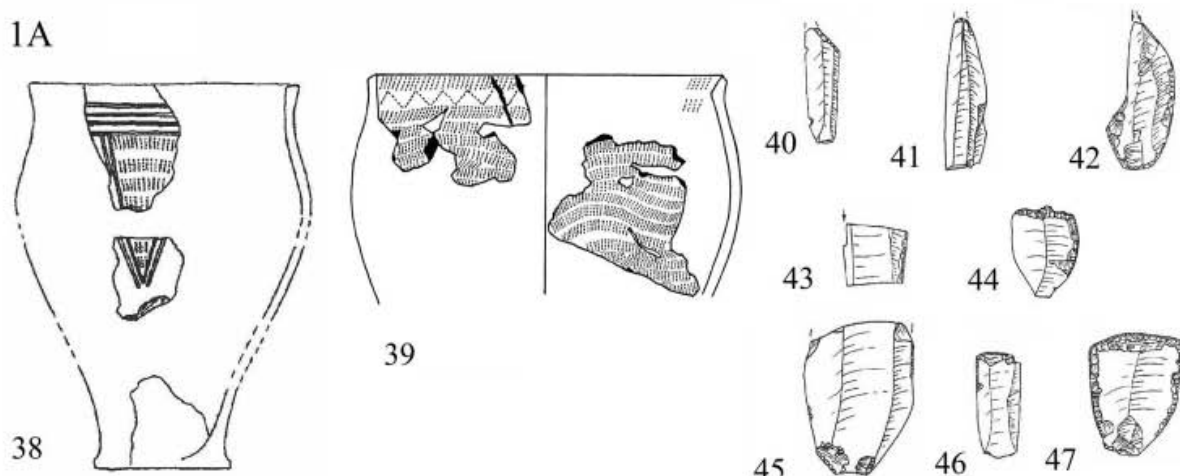

39

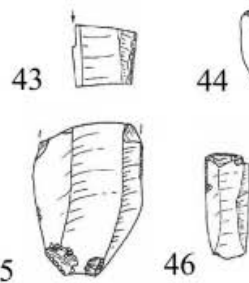

Fig. 2. Materials of the Azov-Dnieper Culture: 1, 4-6, 8, 10, 12-14, 17, 19 - Nikolskoe cemetery (D.Ya. Telegin's excavation); 2, 11 - Lysaya Gora cemetery; 3, 15, 16, 18 - Semenovka 1; 20, 22, 25 - Vovchok; 21, 24 - Vovnigi right-bank site; 28, 29 - Nikolskoe cemetery (A.V. Bodjanskiy's excavation); 26, 27, 30-37 - Vovnigi 2 cemetery; 38 - Babino; 39-47 - Chapaevka 
show a gradual assimilation of the Surskoy people by the Azov-Dnieper population. Some groups borrowed the Azov-Dnieper tradition of long-term use of large burial pits (the second period of the Vilnyanka cemetery) (Kotova 2010). The Vovnigi sites include vessels with an admixture of sand in the clay, and which feature triangular impressions as decorations, which were typical for the second period of the Azov-Dnieper Culture. Finally, the Surskoy people were assimilated by the Azov-Dnieper and Sredniy Stog populations.

Two periods have been identified in the development of the Azov-Dnieper Culture (Danilenko 1974; Kotova 2003). Period 1A is represented by the materials of the Chapaevka, Semenovki 1, and Babino 3 sites. The Mamaj Gora cemetery and burials without ochre from the Vasilievka 5, Vovnigi 2 and Nikolskoye (excavations by A. V. Bodyansky) cemeteries are also representative of this period. Radiocarbon dating based on samples of animal bone from Chapaevka, and on human bone from Mamaj Gora, indicate a date of about 6050-5750 calBC.

Period 1B includes the lower layers of Sobachki, Vovchok, and the right-bank and leftbank sites of Vovnigi, as well as graves with ochre in the Vasilievka 5, Vovnigi 2 and Nikolskoye (excavations by A. V. Bodyansky) cemeteries. Based on the dating of human bones from Vasilievka 5, period 1B encompasses the span between about 5750 and 5300/5200 calBC.

The second period refers to a transition from the Late Neolithic to the Early Eneolithic. Materials from this period are present at the sites of Sobachki, Vovchok, Vovnigi (rightbank and left-bank), Strelcha Skelya, and Kamayna Mohyla 1 and 2, among others; they are also present in the cemeteries of Yasinovatka 1, Nikolskoye, and Lysaya Gora (Kotova 2003). The comb decoration of pottery was replaced by triangular impressions and incised lines. Burials in individual pits located in rows were replaced by burials in large pits, which were used for an extended period of time. Stone accumulations and sacrificial places with broken vessels appeared on the surface of the cemeteries. Based on radiocarbon dates of skeletons and animal bones from settlements, the second period was estimated to span 5300/5200-4750 calBC.

In light of what we now know from new archaeological studies, and taking into account the reservoir effect on radiocarbon dates for human bones, we address below the urgent need to revise the Neolithic chronology of the Dnieper steppe region.

\section{MATERIALS AND METHODS}

The reassessment of the ages of Neolithic cemeteries in the Dnieper Rapids area was carried out as part of the Ukrainian-Swiss project focusing on the adaptation of the ancient population of Ukraine to climate change. Chronological revisions were based on the dating of ornaments made of red deer teeth, which accompanied the Neolithic burials, because they are not subject to the reservoir effect. Samples were taken from the Vovnigi 1 and 2 
cemeteries, which had no previous radiocarbon dates. Red deer teeth from burials at Mamaj Gora, Vovnigi 3, Vilnyanka (Table 1) were also dated, which, together with the dates for such ornaments from the Yasinovatka 1 and Nikolskoye burials made earlier at Oxford Laboratories (Lillie et al. 2009; 2011; 2016), allowed for the correction of the chronological position of these cemeteries, previously estimated using only samples of human bone. New dates have been obtained in the laboratory of Kiev (Ukraine) with conventional liquid scintillation techniques, and in the laboratories at Poznan (Poland) and Bern (Switzerland) using AMS dating. Radiocarbon dates were calibrated using the calibration programme quickcal2007 ver.1.5, calPal_2007_HULU.

\section{RESULTS}

\subsection{Rectification of the age of the Surskoy Culture cemeteries}

The two most reliable dates for animal bones were made for the Vilnyanka cemetery (Table 1). Three chronological groups of graves can be distinguished here (Telegin and Potekhina 1987). The first of these is represented by 28 burials with southern and northern orientations in oval pits. The destruction and overlapping of burials without ochre by ocher-colored burials is recorded. The teeth of a deer from burial 40 and an animal bone from burial 32 were dated, giving a range of about 5300-5130 calBC - early, but not quite the oldest dates from the first group. In general, the first stage of the Vilnyanka cemetery can be dated to around 5350-5100 years BC.

The second stage of the cemetery is connected with 15 burials in three small rectangular pits. The third stage is connected with seven skeletons, which lie above the burials in the sub-rectangular pits. These few burials of the second and third stages could have been constructed over two or three generations and could be dated to about 5100-5000 calBC.

An original Surskoy funerary complex was located and excavated near Yasinovatoy village, Vilnyansky district, Zaporozhye region. It was situated on the third terrace above the floodplain of the left bank of the Dnieper River, lying near the Vovnigi Rapid and the multilayer Vovnigi left-bank site, which includes materials from the third period of the Surskoy Culture (Kotova 2010). There, at a distance of 40-60 m from each other, three cemeteries were located: Vovnigi 1, and 3 and Yasinovatka 1 (first and second chronological groups). The burials were in individual pits situated in rows, with skeletons in a southern orientation - some with ochre and some without. Similar grave goods attest to the simultaneity of these cemeteries. The good state of preservation of the Vovnigi 1 and Yasinovatka 1 cemeteries allows us to establish their relatively long duration, in which different horizons of burials were formed. At the same time, the low number of burials in each cemetery (30 skeletons at most) indicates that they belonged to small groups of people. Currently, all three cemeteries are dated. 
Table 1. Radiocarbon dates for animal bones of the Surskoy Culture

\begin{tabular}{|c|c|c|c|c|}
\hline Monument & Material & Index & BP & $\begin{array}{l}\text { quickcal2007 ver.1.5, } \\
\text { calPal_2007_HULU }\end{array}$ \\
\hline \multicolumn{5}{|c|}{ First period } \\
\hline Surskoy island 2, lower layer & Animal bone & Ki-6691 & $7245 \pm 60$ & $6113 \pm 70$ \\
\hline Surskoy island 2, lower layer & Animal bone & Ki-6690 & $7195 \pm 55$ & $6065 \pm 53$ \\
\hline Semenovka 1 , lower layer & Animal bone & Ki-7679 & $7285 \pm 70$ & $6140 \pm 67$ \\
\hline Semenovka 1, lower layer & Animal bone & Ki-6689 & $7125 \pm 60$ & $5979 \pm 57$ \\
\hline $\begin{array}{l}\text { Kamyana Mohyla 1, } \\
\text { first ceramics layer }\end{array}$ & Animal bone & $\mathrm{Ki}-4022$ & $7250 \pm 95$ & $6116 \pm 89$ \\
\hline Kamyana Mohyla 1, first ceramics layer & Animal bone & Ki-4226 & $7170 \pm 70$ & $6028 \pm 69$ \\
\hline Kamyana Mohyla 1, first ceramics layer & Animal bone & Ki-7667 & $7055 \pm 60$ & $5920 \pm 58$ \\
\hline $\begin{array}{l}\text { Kamyana Mohyla } 1,2011, \text { trench } 1, \\
\text { sq.3,98-107 cm }\end{array}$ & Cattle bone & $\begin{array}{c}\text { Poz- } 513020.8 \% \mathrm{~N} \\
4.0 \% \mathrm{C} \\
\end{array}$ & $7075 \pm 35$ & $5960 \pm 36$ \\
\hline \multicolumn{5}{|c|}{ Second period } \\
\hline Kizlevy 5 & Animal bone & Ki-7999 & $6740 \pm 90$ & $5641 \pm 74$ \\
\hline $\begin{array}{l}\text { Kamyana Mohyla 1, brown soil with } \\
\text { abundant carbonates }\end{array}$ & Animal bone & $\mathrm{Ki}-4025$ & $6376 \pm 60$ & $5378 \pm 64$ \\
\hline $\begin{array}{l}\text { Kamyana Mohyla 1, brown soil with } \\
\text { abundant carbonates }\end{array}$ & Animal bone & $\mathrm{Ki}-4024$ & $6180 \pm 90$ & $5130 \pm 115$ \\
\hline $\begin{array}{l}\text { Kamyana Mohyla 1, brown soil with } \\
\text { abundant carbonates }\end{array}$ & Animal bone & $\mathrm{Ki}-4023$ & $6120 \pm 80$ & $5069 \pm 115$ \\
\hline Strilcha Skelja, sq. 8, shtyk 9, 509 & Animal bone & $\mathrm{Ki}-8174$ & $6290 \pm 65$ & $5254 \pm 80$ \\
\hline Vilnyanka cemetery, burial 40 & $\begin{array}{l}\text { Tooth of red } \\
\text { deer }\end{array}$ & Ki-14874 & $6290 \pm 60$ & $5233 \pm 85$ \\
\hline Vilnyanka cemetery, burial 32 & Animal bone & OxA-17497 & $6252 \pm 36$ & $5206 \pm 74$ \\
\hline Vovnigi 3 cemetery & $\begin{array}{l}\text { Tooth of red } \\
\text { deer }\end{array}$ & Poz-61517 & $6230 \pm 35$ & $5195 \pm 83$ \\
\hline Yasinovatka 1 cemetery, burial 54 & $\begin{array}{l}\text { Tooth of red } \\
\text { deer }\end{array}$ & OxA-17500 & $6121 \pm 34$ & $5061 \pm 76$ \\
\hline Vovnigi 1, burial 25 & $\begin{array}{l}\text { Tooth of red } \\
\text { deer }\end{array}$ & Poz-51301 & $6170 \pm 40$ & $5129 \pm 62$ \\
\hline
\end{tabular}

Two dates were made for Vovnigi 3 (Tables $1 ; 2$ ), which was excavated by S. N. Lyashko and S. N. Kravchenko in 1985 (Kotova and Kravchenko 1992). It included 11 burials with a southern orientation in individual pits. The skeletons were painted with ocher. Their grave goods consisted of flint and stone products, as well as bone points. Funerary clothing was decorated with nacreous beads and pendants from the teeth of a red deer.

The date from skeleton 3 , collective burial 4 , yields a range of about 5200-5000 calBC. It is interesting that the date obtained from a red deer tooth from the same cemetery (in context with an unknown skeleton) is older than the date yielded by skeleton 3: about 5280-5100 calBC. This fact suggests that there is no reservoir effect, or it was weak in the bones of skeleton 3. Radiocarbon dates from Vovnigi 3 suggest a range of about 53005000 calBC. 
Table 2. Radiocarbon dates for human bones from the Surskoy Culture cemeteries in the Dnieper valley

\begin{tabular}{|l|l|c|c|c|}
\hline \multicolumn{1}{|c|}{ Cemetery } & Material & Index & BP & $\begin{array}{c}\text { quickcal2007 ver.1.5, } \\
\text { calPal_2007_HULU }\end{array}$ \\
\hline $\begin{array}{l}\text { Yasinovatka 1 cemetery, stage 1, } \\
\text { burial 54 }\end{array}$ & Human bone & OxA-17499 & $6593 \pm 35$ & $5551 \pm 42$ \\
\hline $\begin{array}{l}\text { Yasinovatka 1 cemetery, stage 1, } \\
\text { burial 5 }\end{array}$ & Human bone & OxA-6163 & $6465 \pm 60$ & $5427 \pm 52$ \\
\hline $\begin{array}{l}\text { Yasinovatka 1 cemetery, stage 1, } \\
\text { burial 19 }\end{array}$ & Human bone & OxA-6165 & $6370 \pm 60$ & $5373 \pm 66$ \\
\hline $\begin{array}{l}\text { Yasinovatka 1 cemetery, stage 1, } \\
\text { burial 64 }\end{array}$ & Human bone & OxA-5030 & $6330 \pm 90$ & $5314 \pm 101$ \\
\hline $\begin{array}{l}\text { Yasinovatka 1 cemetery, stage 1, } \\
\text { burial 21 }\end{array}$ & Human bone & Ki-6789 & $6295 \pm 70$ & $5259 \pm 89$ \\
\hline $\begin{array}{l}\text { Yasinovatka 1 cemetery, stage 1, } \\
\text { burial 41 }\end{array}$ & Human bone & Ki-6785 & $6240 \pm 95$ & $5188 \pm 116$ \\
\hline $\begin{array}{l}\text { Yasinovatka 1 cemetery, stage 1, } \\
\text { burial 39 }\end{array}$ & Human bone & Ki-6790 & $5860 \pm 75$ & $4723 \pm 94$ \\
\hline $\begin{array}{l}\text { Yasinovatka 1 cemetery, stage 2, } \\
\text { burial 17 }\end{array}$ & Human bone & OxA-6166 & $6360 \pm 75$ & $5349 \pm 86$ \\
\hline $\begin{array}{l}\text { Yasinovatka 1 cemetery, stage 2, } \\
\text { burial 18 }\end{array}$ & Human bone & OxA-6167 & $6255 \pm 65$ & $5204 \pm 93$ \\
\hline $\begin{array}{l}\text { Vovnigi 3 cemetery, grave 4, } \\
\text { skeleton 3 }\end{array}$ & Human bone & Ki-14876 & $6130 \pm 80$ & $5078 \pm 112$ \\
\hline
\end{tabular}

The Vovnigi 1 cemetery was excavated by M. Ya. Rudynsky in 1949 (Rudinskiy 1956). Although partially destroyed, 37 burials were investigated. In the earliest phase of the cemetery, burials were in individual pits, often intersected or cut by later burials. Analysis of this sequence of burials allows four chronological groups to be distinguished (Kotova 1994). An additional stage was connected with a child's burial from the Azov-Dnieper Culture, excavated near the accumulation of Surskoy burials. It was accompanied by fragments of a typical Azov-Dnieper vessel. A radiocarbon date was obtained from a red deer tooth pendant, which decorated the clothes of burial 25 (Table 1). It was found to be from about 5190-5070 calBC. This burial was one of the oldest in the cemetery. Taking into account this date, as well as the similarity of the burial rite of this cemetery to Vilnyanka and Vovnigi 3, Vovnigi 1 can be placed at around 5250-5000 calBC.

The most numerous radiocarbon dates come from the Yasinovatka 1 cemetery, which includes three groups of burials (Telegin and Potekhina 1987). The skeletons of the oldest group, found in small, individual pits, were oriented toward the south, with graves partially overlapping one another, occasionally resulting in serious damage. The burial rites and grave goods of this group are similar to Vovnigi 1. Burials 5, 19, 21, 39, 41, 54, and 64 have been dated (Tables $1 ; 2$ ). The human bones yielded a date range of about $5600-5300$ calBC. However, red deer tooth pendant from burial 54 gave a date of 5140-4980 calBC. This burial shows a reservoir effect of about 470 years. The date closest to that of the red 
deer tooth comes from skeleton 41, which belonged to a child aged 6-7 years $(5188 \pm 116$ calBC). Evidently, the bones of this child show a minimal reservoir effect in comparison with the bones of the adult skeletons.

Interestingly, a vegetarian diet was reconstructed for burial 19 (Lillie et al. 2009, 261). However, it dates from about 5430-5310 calBC, which is at least 200 years older than the dates of the deer teeth from burial 54 . Skeleton 19 was not painted with ocher, which indicates that it belongs to the oldest group of burials of stage 1 - those without ochre, which were later destroyed by painted burials. Burial 54 displayed ocher coloration, which shows its younger age in comparison with burial 19. However, judging by the stratigraphic relationship of the burials, the time difference between these two skeletons was no more than three generations (about 80 years). Therefore, it is possible that a reservoir effect occurred even in the case of Neolithic vegetarians from this region. If this is correct, then the reservoir effect here is caused not only by the consumption of fish and other aquatic animals, and additional research is needed. It should be noted that isotopic analyses of these Ukrainian cemeteries are still in the beginning stages, and this result may be a methodological error.

Burial 39 yielded the youngest date among human remains at the Yasinovatka 1 cemetery: about 4820-4630 calBC. This individual was found in a shallow, oval pit (A-3) underneath pit $\mathrm{B}$, which had a red filling belonging to the second period of the Azov-Dnieper Culture. We cannot explain this young age at the present moment. Further research is needed to confirm the validity of this date. Generally, stage 1 of the Yasinivatka 1 cemetery can be dated at about 5200-5000 calBC.

The burials of the second stage had a northern orientation. Two of them have been dated: skeletons 17 and 18 both yield a range of about 5350-5100 calBC. However, isotopic studies indicate a diet heavy in freshwater fish protein for both skeletons, suggesting that their radiocarbon dates should be corrected to take the reservoir effect into account. Judging by the dates associated with burials of stage 1 , which were obtained from samples of animal bone, we think that burials of stage 2 must be from no earlier than 5000 calBC.

Earlier, it was assumed that the Vasilievka 2 and Maryevka cemeteries attributed to the Late Mesolithic might have been the most ancient cemeteries of the Surskoy Neolithic Culture (Kotova 2010). The age of these cemeteries yielded by human bones, falling between 6900-6300 calBC (Table 3). Like the younger Surkoy burials, they have the north and south orientation of the skeletons, small flint blades medium-high trapezoids, and fish teeth among the grave goods. Bone bracelets from Vasilievka 2 have linear ornaments, which are similar to the ornamentation found on the Surskoy bone tools at Kizlevy 5 and Sursky Island 1 (Kotova and Tuboltsev 2013, fig. 7, 6-13).

Isotope studies have shown that freshwater resources contributed greatly to the diets of individuals at Vasilievka 2 (Lillie et al. 2011). Similar isotopic signatures are also characteristic for one individual from Marievka (burial 10). It is interesting that burial 10 at Marievka, with a correction for the reservoir effect, has a younger date than burials 4 and 
Table 3. Radiocarbon dates for the Mesolithic cemeteries of the Dnieper valley

\begin{tabular}{|l|c|c|c|c|}
\hline \multicolumn{1}{|c|}{ Cemetery } & Material & Index & BP & $\begin{array}{c}\text { quickcal2007 ver.1.5, } \\
\text { calPal_2007_HULU }\end{array}$ \\
\hline Vasilievka 2 & Human bone & OxA-3806 & $8020 \pm 90$ & $69191 \pm 141$ \\
\hline Vasilievka 2 & Human bone & OxA-3804 & $7920 \pm 85$ & $6840 \pm 144$ \\
\hline Vasilievka 2 & Human bone & OxA-3805 & $7620 \pm 80$ & $6474 \pm 74$ \\
\hline Marievka, burial 4 & Human bone & OxA-6199 & $7955 \pm 50$ & $6876 \pm 119$ \\
\hline Marievka, burial 4 & Human bone & Ki-6782 & $7680 \pm 90$ & $6533 \pm 79$ \\
\hline Marievka, burial 14 & Human bone & OxA-6269 & $7630 \pm 110$ & $6477 \pm 111$ \\
\hline Marievka, burial 14 & Human bone & Ki-7600 & $7650 \pm 100$ & $6505 \pm 91$ \\
\hline Marievka, burial 10 & Human bone & OxA-6200 & $7620 \pm 100$ & $6465 \pm 102$ \\
\hline Marievka, burial 10 & Human bone & Ki-6781 & $7585 \pm 80$ & $6405 \pm 84$ \\
\hline Marievka, burial 10 & Human bone & Ki-6779 & $7550 \pm 80$ & $6369 \pm 80$ \\
\hline
\end{tabular}

14, for which a terrestrial diet has been reconstructed. Aside from this correction, we have the same situation here as with burial 19 from the Yasinovatka 1 cemetery, for which a vegetarian diet is indicated.

If we assume that the reservoir effect impacted the available dates from Marievka and Vasilievka 2, and we apply a 300-500 year correction for the reservoir effect in the Mesolithic and Early Neolithic burials in the ecologically similar region of the Danube rapids (Borić et al. 2008), then Marievka and Vasilievka can be determined to date from about 6500-6000 calBC. They can thus be synchronized with the oldest Surskoy settlements.

\subsection{Rectification of the age of Azov-Dnieper cemeteries}

The Mamaj Gora cemetery, on the left high bank of the Dnieper River, was excavated by G. N. Toshchev and O. V. Tuboltsev in 1988-2002 (Toscev 2005). It includes 26 burials of the first period of the Azov-Dnieper Culture. A single individual was interred in each grave pit, and these were arranged in a row. The skeletons were oriented to the east. A majority of the burials contained ornaments from funerary clothing (pendants from deer teeth, nacreous and stone beads). Grave goods included flint tools, among them two trapezes with flat retouch on the back. Three radiocarbon dates were made for human bones from burials 6, 7 and 9 (Table 5), which yielded dates between about 5950-5750 calBC (Kotova 2003).

In order to gauge the impact of a potential reservoir effect, we decided to compare additional dates obtained from samples of deer-tooth pendants and human bone from burial 
Revisiting the Neolithic chronology of the Dnieper steppe region with consideration...

Table 4. Radiocarbon dates for the Azov-Dnieper Culture (animal bones)

\begin{tabular}{|l|c|c|c|c|}
\hline \multicolumn{1}{|c|}{ Site } & Material & Index & BP & $\begin{array}{c}\text { quickcal2007 ver.1.5, } \\
\text { calPal_2007_HULU }\end{array}$ \\
\hline Chapaevka, sq. 3, depth 64 cm & Animal bone & Ki-7670 & $6910 \pm 60$ & $5806 \pm 62$ \\
\hline Chapaevka, sq. 6, depth 64 cm & Animal bone & Ki-7671 & $7030 \pm 70$ & $5908 \pm 72$ \\
\hline Mamaj Gora, burial 1 & Tooth of red deer & Poz-61516 & $6250 \pm 40$ & $5220 \pm 69$ \\
\hline Mamaj Gora, burial 35 & Tooth of red deer & LARA-6734.1.1 & $6392 \pm 22$ & $5392 \pm 51$ \\
\hline $\begin{array}{l}\text { Vovnigi 2, burial 45 (or burial 3 of } \\
\text { the central part of cemetery } \\
\text { according the field's numbers) }\end{array}$ & Tooth of red deer & Poz-51300 & $6055 \pm 30$ & $4962 \pm 39$ \\
\hline Nikolskoye cemetery, burial 55 & Tooth of red deer & Poz-61515 & $5850 \pm 35$ & $4728 \pm 41$ \\
\hline Nikolskoye cemetery & Tooth of animal & OxA-17493 & $6020 \pm 34$ & $4915 \pm 51$ \\
\hline
\end{tabular}

35. Unfortunately, the human bone did not contain enough collagen for dating. We also sent deer teeth from burial 1 for additional analysis. The two dates obtained from the reddeer teeth give a range of about 5440-5150 calBC (Table 4), which suggests a reservoir effect in the human bone samples of about 500-600 years.

The Vovnigi 2 cemetery also belonged to the first period of the Azov-Dnieper Culture. It was excavated by A. V. Bodyansky and M. Ya. Rudinsky in 1952 near the village Vovnigi, Solonyansky district, Dnipropetrovsk Region (Bodyanskiy and Kotova 1994). Located on the right bank of the Dnieper River, it included 131 burials. A majority of the burials had a western orientation, with one exception oriented to the east. The burials formed three rows, in which the younger interments frequently overlapped and destroyed older ones. The first stage includes 42 burials without ochre, whereas the second stage is represented by 87 skeletons with ochre.

Burial 45 (or burial 3 of the central part of the cemetery in terms of field numbering) was painted with ocher, and included red-deer teeth located on the skull and a shell fragment in the chest area (genus Unio). The lower part of the skeleton was destroyed by a modern pit. Using a sample of reddeer tooth, we obtained a radiocarbon date of about 5010-4920 calBC for this burial (Table 4).

The first period of the Azov-Dnieper Culture also includes materials from the Vasilyevka 5 cemetery. Analysis of the burial sequence shows two stages (Kotova 2003). The first stage comprises 17 graves without ochre and two others slightly colored with ochre. Radiocarbon dates have been obtained from two of the burials from stage 1. Burial 10 dates to approximately 5610-5510 calBC, and burial 23 to about 5550-5410 calBC (Table 5). The second stage includes 19 burials with ochre, lying above those that are unpainted. Burial 20 yielded a date range of 5800-5650 calBC; burial 8, about $5480-5380$ calBC; burial 26, which is represented by a skull, dates to about $5400-5250$ calBC; burial 29 gives a date of about 5320-5240 calBC. 
Table 5. Radiocarbon dates for the Azov-Dnieper Culture (human bones)

\begin{tabular}{|c|c|c|c|c|}
\hline Monument & Material & Index & BP & $\begin{array}{l}\text { quickcal2007 ver.1.5, } \\
\text { calPal_2007_HULU }\end{array}$ \\
\hline \multicolumn{5}{|c|}{ First period } \\
\hline Mamaj Gora, burial 6 & Human bone & $\mathrm{Ki}-8183$ & $7055 \pm 70$ & $5929 \pm 67$ \\
\hline Mamaj Gora, burial 7 & Human bone & $\mathrm{Ki}-8182$ & $7150 \pm 70$ & $6020 \pm 67$ \\
\hline Mamaj Gora, burial 9 & Human bone & $\mathrm{Ki}-8184$ & $6960 \pm 70$ & $5853 \pm 80$ \\
\hline Vasilievka 5 , burial 8 & Human bone & OxA-6171 & $6470 \pm 60$ & $5430 \pm 52$ \\
\hline Vasilievka 5 , burial 10 & Human bone & OxA-6172 & $6805 \pm 60$ & $5702 \pm 43$ \\
\hline Vasilievka 5, burial 10 & Human bone & Ki-6772 & $6620 \pm 80$ & $5563 \pm 57$ \\
\hline Vasilievka 5, burial 20 & Human bone & OxA-6268 & $6710 \pm 90$ & $5628 \pm 72$ \\
\hline Vasilievka 5, burial 23 & Human bone & Ki-6771 & $6530 \pm 70$ & $5484 \pm 71$ \\
\hline Vasilievka 5, burial 26 & Human bone & Ki-6775 & $6325 \pm 65$ & $5312 \pm 72$ \\
\hline Vasilievka 5, burial 29 & Human bone & OxA-6198 & $6280 \pm 70$ & $5232 \pm 93$ \\
\hline Vasilievka 5, burial 29 & Human bone & Ki-6776 & $6220 \pm 60$ & $5178 \pm 92$ \\
\hline \multicolumn{5}{|c|}{ Second period } \\
\hline Lysaya Gora, pit 4 & Human bone & Ki-8181 & $5890 \pm 70$ & $4768 \pm 81$ \\
\hline Yasinovatka 1, burial 34 & Human bone & Ki-6786 & $6195 \pm 80$ & $5150 \pm 105$ \\
\hline Yasinovatka 1, burial 36 & Human bone & OxA-5057 & $6260 \pm 80$ & $5206 \pm 105$ \\
\hline Yasinovatka 1, burial 45 & Human bone & Ki-6791 & $6305 \pm 80$ & $5268 \pm 102$ \\
\hline Yasinovatka 1, burial 45 & Human bone & OxA-6164 & $6360 \pm 75$ & $5349 \pm 86$ \\
\hline Nikolskoye, burial 125 & Human bone & OxA-5029 & $6300 \pm 80$ & $5260 \pm 104$ \\
\hline Nikolskoye, burial 94 & Human bone & OxA-6155 & $6225 \pm 75$ & $5175 \pm 101$ \\
\hline Nikolskoye, burial 137 & Human bone & OxA-5052 & $6145 \pm 70$ & $5098 \pm 96$ \\
\hline Nikolskoye, burial 23 & Human bone & OxA-6206 & $3450 \pm 70$ & $1775 \pm 92$ \\
\hline Nikolskoye, burial 36 & Human bone & OxA-6157 & $3175 \pm 50$ & $1458 \pm 41$ \\
\hline Nikolskoye, burial 58 & Human bone & OxA-6156 & $2305 \pm 45$ & $333 \pm 69$ \\
\hline
\end{tabular}

Isotope analysis for burial 29 (which yielded the youngest radiocarbon date) does not show a significant role for fish in the diet (Lillie and Richards 2000, 967). However, even in this case, the reservoir effect cannot be excluded. Taking into account the fact that burial 29 belongs to the second period of the cemetery, and also taking into account the reservoir effect of about 400-500 years for the Neolithic burials, as well as the dates for the similar Mamaj Gora and Vovnigi 2 cemeteries, we can narrow the chronology of Vasilyevka 5. If stage 1 of Vasilievka 5 is dated at about 5700-5400 calBC, and stage 2 about 5400-5200 calBC, taking into account the reservoir effect, we can assume that the cemetery dates between 5450-4900 calBC. 
Yasinovatka 1 includes a group of burials of the Azov-Dnieper Culture in a large rectangular pit (30 sq.m.) with painted fill, which relates to stage 3 of the functioning of the cemetery. Groups of stones were located above the pit, and in the fill were bone and flint products, ceramics, and animal and fish bones. The burials inside were oriented to the east and formed a strip where the younger skeletons overlapped and destroyed the older ones. There are 18 burials: 3, 6, 6a-b, 7, 12a-d, 24, 32a, 34-36, 45, 47a and 50. The remaining skulls found in the area of the pit may belong to the destroyed burials of any of three chronological groups. Three burials (34, 36 and 45; Table 5) were radiocarbon dated based on human bone samples, yielding a range of about 5300-5150 calBC. Burials 36 and 45, in particular, gave the most ancient dates (Lillie et al. 2009; 2011) and exactly isotopic analysis of burial 36 and 45 indicates a large role of river fish in the diet. Taking into account the date for the reddear tooth from the burial of the first period of this cemetery (5140-4980 calBC), we can assume that the date of the Azov-Dnieper funeral pit was about 4900-480o calBC.

A series of radiocarbon dates was made for human bones from the Nikolskoye cemetery. Excavation of the cemetery was begun by A.V. Bodyansky in 1948 (1959). The study was continued by D. Ya. Telegin in 1959 and 1967 (Telegin and Potekhina 1987). The cemetery was located near the village of Nikolskoye, Solonyansky district, Dnipropetrovsk Region on the right bank of the Dnieper River. A. V. Bodyansky excavated nine burials of the ancient part of this cemetery. They were in individual pits arranged in a row and had western and eastern orientations. Some of the burials were painted with ocher. The grave goods included flint tools, pendants from reddeer teeth, and nacreous and stone beads. There were separate pieces of granite on the ancient surface.

D. Ya. Telegin excavated a part of the cemetery with a large ocher spot (about 6o square meters) on the surface. Human bones, stone and bone tools, fragments of ceramics, and groups of stones were in this location. Four groups of destroyed human bones with decorations, ceramics and flint tools were discovered in the area of the cemetery - apparently remains of destroyed burials. Sixteen burials in individual pits and 11 communal pits were also investigated. The communal pits were used over a long period of time and contained multiple skeletons. A total of 137 burials were excavated.

Due to the fact that very young dates were obtained for this cemetery, it is necessary to describe its stratigraphy in more detail.

A very young date was obtained for burial 23 from pit $B$. This pit had a rectangular shape and an entrance. Its dimensions were $400 \times 300 \mathrm{~cm}$ in the upper part, and $200 \mathrm{x} 200 \mathrm{~cm}$ in the lower part and it had a depth of $185 \mathrm{~cm}$. The fill was colored with ocher. The upper part of the pit contained some kind of burnt wooden covering under a group of stones. There were fragments of pottery and a mace. Fifteen skulls and scattered bones were found in the filling of the pit. Above these skeletons, and under the layer of burnt material and in its lower part, four relatively full skeletons occurred. A bone sample from burial 23 was dated at about $3450 \pm 70 \mathrm{BP}$. It lay in the lower part of the burnt layer, with its head oriented to the west, and it was charred. The lower part of the body and the hands were destroyed. 
An even younger date $(3175 \pm 50 \mathrm{BP})$ was obtained for burial 36 from the southern part of pit G. It contained the bones of six skeletons in anatomical disorder. Burial 36 is represented by a skull without grave goods.

The next youngest date was obtained from burial 58 , in the northern part of pit G. In the upper section of this region of the pit were eight destroyed skeletons. Below these lay two complete skeletons, the lowest of which was burial 58. The skeleton had no grave goods and was oriented to the west. A sample of human bone from this individual yielded a date of about $2305 \pm 45 \mathrm{cal} \mathrm{BP}$.

Judging by the radiocarbon dates from burials 23, 36 and 58, it can be assumed that the same large pits with colored fill attracted the attention of both Bronze Age and Iron Ages populations, and were secondary used. Confirming this hypothesis, however, necessitates that we acquire new dates for these skeletons.

Pit B partially cut through the upper fill of the northern part of pit G, but itself was blocked by the burnt layer of pit B. It had a sub-rectangular shape $(2.2 \times 1.6 \mathrm{~m})$ and a fill with an admixture of ocher. Its depth from the modern surface was about $1.35 \mathrm{~m}$. Destroyed parts of four skeletons, decorations from stone, bone and fish teeth, as well as three fragments of ceramics were found in the fill. There were also two full skeletons (a 35-45 yearold male and a 20-25 year-old female) at the bottom of the pit. At the left shoulder of the man lay about 50 fish teeth and six pendants from the teeth of a red deer. One pendant is dated (Table 4) to about 4770-4690 calBC.

Pit $\mathrm{E}$ had an alcove in its northern wall. Seven full skeletons lay at the bottom of the pit, along with four destroyed skeletons in the upper part. The sample for radiocarbon dating was taken from the uppermost skeleton - burial 125. This individual did not have grave goods. The skeleton lay crookedly on its back in a western orientation, legs arranged in a rhomboid fashion. It yielded a date of 5450-5050 calBC (Table 5).

Pit 3 , which also had walls with alcoves, contained the remains of 41 skeletons. Six relatively well-preserved skeletons and 37 bone fragments from destroyed skeletons occurred in the lower part. In the middle section was another group of bones with a full skeleton lying above it. The upper section showed evidence of burning and included charred skulls and bones, among which two full skeletons (89 and 90) were found. Bone samples from burials 94 (partial skeleton; upper part of pit ) and 137 (complete skeleton) yielded radiocarbon dates of 5350-4900 calBC and 5300-4850 calBC, respectively (Table 5).

The animal tooth found at the Nikolskoye cemetery was also dated. It was found to be from about 4970-4860 calBC (Table 4), which is older than the date obtained from the deer tooth from pit B (4770-4690 calBC). It can be assumed that the more ancient animal tooth fixes the beginning of the functioning of the large pits. It is associated with either sacrifices on the surface of the cemetery, or with the oldest burials destroyed during the construction of the large pits.

Comparing a few of the dates obtained from human bone samples from Nikolskoye cemetery with the dates from animal teeth shows a reservoir effect in the human bones of 
300 to 500 years. This effect was confirmed by isotopic analyses of the bones of seven skeletons, which indicated the important role of freshwater resources in their diet (Lillie $e t$ al. 2011).

Analysis of the sequence of burials allows us to assume a rather short period of existence for the Nikolskoye cemetery. Perhaps it was used for four to five generations, and each large pit was a family burial vault. Correction of the dating of the part of the Nikolskoye cemetery excavated by D. Ya. Telegin suggests that it was in use from about 4900 (at which time, burials were in individual pits) to 4700 calBC. It is possible to date the extended-use communal pits to about 4850-4700 calBC. This cemetery was synchronous with Trypillya A (Kotova 2003), and E. N. Chernykh's study of metal objects from the Nikolskoye cemetery has shown its similarity with Trypillya A copper (Chernykh 1966).

Lysaya Gora cemetery was excavated by A. Bodyansky in 1959. It was located in $5 \mathrm{~km}$ to the west of Vasilyevka, Zaporozhye region, on the loess terrace of the left bank of the Dnieper River. An ocher spot with an area of about 21 sq. m was traced at a depth of $70-90 \mathrm{~cm}$. In the fill, fragments of vessels, human and animal bones, shells, flint and bone tools were found.

A.V. Bodyansky distinguished three groups of graves. Group 1 includes five or six skeletons without traces of pits. Group 2 includes five oval and rounded pits. Group 3 is represented by two cremations, which were located above one of the pits. Grave goods from the area around and including the pits and cremations suggest a connection of the majority of burials to the second period of the Azov-Dnieper Culture (Kotova 1994, 35). A sample from the skeleton in pit 4 is dated to $5890 \pm 70$ BP (Ki-8181) (Table 5). Pit 4 had the shape of an oval with dimensions of $215 \times 120 \mathrm{~cm}$, and its fill was perfused with ochre. It contained the remains of one complete, and five destroyed skeletons of adults. The pit 4 overlapped the pit 5 .

Judging by the radiocarbon date, the latest burials of the cemetery were made at about 4850-4690 calBC. The ceramics and ornaments of Lysaya Gora are identical to those from the large pits of the Nikolskoye cemetery, which is dated at about $4850-4700$ calBC. This assumes the absence of a reservoir effect for the Lysaya Gora skeletons.

The Chapaevka site is a unique monument with one cultural layer, including materials from the oldest period (1A) of the Azov-Dnieper Culture (Kotova 2003). It occupies the northern slope of the promontory of the right above-flood terrace of the Molochnaya River near the Chapaevka village of Tokmak district of Zaporozhye region. It was investigated by Yu. Ya. Rassamkin and N. S. Kotova in 1989-1990. 120 sq. m were excavated. Radiocarbon dates were made on the animal bones (Table 4). They determine the site age at about $5950-5750$ calBC.

The Kamyana Mohyla 1 multilayer site is located on the first terrace above the flood plain on the right bank of the Molochnaya River in the area of the Kamyana Mohyla National Museum-Reserve, $2 \mathrm{~km}$ to the east of Mirnoe village, Melitopol district, Zaporozhye region. At present, it is only site in the Ukrainian steppe where the cultural layers from the 
Early Mesolithic to the Late Eneolithic are consistently and most fully represented, formeing a clear stratigraphic column. The settlement was investigated in 1936 and 1938 by O. N. Bader (20 sq.m.), in 1947 (113 sq. m.) and 1969-73 by V. N. Danilenko, and in 1983 and 1987 years by D. Ya. Telegin (50 sq.m.).

V. N. Danilenko (1986) and D. Ya. Telegin (1990) noted a different set of cultural layers on this site, associated with a few fragments of ceramics, which are the most reliable chronological indicator. N. S. Kotova carried out a study of old collections and a comparison of findings with field drawings, as well as a reconstruction of the stratigraphy (Kotova 2003). The following picture was emerged from these studies: a layer from the Middle Eneolithic with ceramics; a layer from the Early Eneolithic - specifically, the second period of the Sredniy Stog Culture (4580-4270 calBC); a layer from the second period of the AzovDnieper Culture (5300-4900 calBC) below a layer from the Surskoy Culture (6100-5900 calBC), which overlaps some Mesolithic layers.

In the framework of the joint Ukrainian-Swiss project in 2011, new excavations of the site began (Kotova et al. 2017). They showed that the materials of the second period of the Azov-Dnieper Culture lie directly over the materials of the second period of the Surskoy Culture. The Azov-Dnieper materials are confined to the upper horizon of the brown soil with large carbonates, and the Surskoy materials are found in the lower horizon of this soil layer. The bones obtained by D. Ya. Telegin from this soil layer date to about 5300-4900 calBC (Table 4). Earlier, D. Ya. Telegin and N. S. Kotova believed that they dated the AzovDnieper materials, because the Surskoy pottery was absent in the old collection, and these dates were close to the dates obtained from human bones from the Nikolskoye cemetery, which had ceramics similar to pottery from the upper horizon of the fifth soil layer of Kamayna Mohyla 1 (Telegin 1990; Kotova 2003). However, data from the cemeteries of the Dnieper rapids considered above - which have been revised to take into account the reservoir effect - show that the cemeteries of the second period of the Azov-Dnieper Culture date from about 4900-4700 calBC. At the same time, dates from animal bones from the cemeteries of the second period of the Surskoy Culture give a range of about 5300-4900 calBC (Table 1). These facts show a connection between the dated bones from the fifth soil horizon and the underlying layer of second period of the Surskoy Culture, which has been clearly distinguished after new excavations.

The upper part of the sixth soil layer (light loam with manganese strokes) contains materials of the first period of the Surskoy Culture. Radiocarbon dates for the animal bones from new and old excavations date this cultural layer to about 6100-5950 calBC (Table 1).

The multilayered site of Strilcha Skelya on an island in the Dnieper River, opposite Voloshskoye village, Dnipropetrovsk Region, was investigated in 1946 by V. N. Danilenko and A. V. Dobrovolsky, in 1986 by D. Ya. Telegin, and in 1989 by I. F. Kovaleva. Analysis of the materials shows a lack of a clear stratigraphy, due to the excavation of the sandy soil using shovels, and using horizons of about $20 \mathrm{~cm}$. 
There is a layer with materials of the second period of the Surskoy Culture that is covered with a layer of the second period of the Azov-Dnieper Culture. As at Kamyana Mohyla 1, these layers were not separated by a sterile interlayer. A radiocarbon date was made for a bone tool from Strilcha Skelya, yielding a date of 6290 \pm 55 BP (Ki-8174), which was associated with the materials of the second period of the Azov-Dnieper Culture (Kotova 2003). In light of new data for the cemeteries, this date should be correlated with the second period of the Surskoy Culture.

\section{DISCUSSION}

As we can see, some interpretations of the results of isotope analyses of Neolithic skeletons from the Ukrainian steppe need additional data and further development. However, it is possible to make preliminary conclusions.

An important problem is the beginning of the Neolithic in southern Ukraine, which is associated with the appearance of Surskoy Culture sites. This culture was formed on the foundation of the Mesolithic Kukrek Culture, as a result of contacts with the Neolithic newcomers (Kotova 2015). At present, the oldest known sites of the culture are Surskoy Island 1 in the Dnieper, Semenovka 1 and Kamyana Mohyla 1 in the adjacent Azov Sea area. On the basis of samples from animal bones, the first period of the Surskoy Culture is dated at about 6200-5900 calBC (Table 1), but the possibility that the formation of this culture took place 100-200 years earlier cannot be excluded. It is possible that, after correction for the reservoir effect, the youngest burials of the Vasilievka 2 and Marievka cemeteries were connected with the oldest Surskoy sites.

Later, in the Dnieper steppe and Western Azov Sea regions, the population of the AzovDnieper Culture appeared. They coexisted with the Surskoy people and kept contacts with them, which was reflected in an appearance of the Azov-Dnieper elements in the Surskoy ceramics (Kotova and Tuboltsev 1992). The one-layered Chapaevka site is the oldest and belonged to period $1 \mathrm{~A}$ of the Azov-Dnieper Culture. Dates from animal bones from the Chapaevka site determine the beginning of the Azov-Dnieper Culture to be at about 5950-

Table 6. Old and new ages for the Azov-Dnieper and Surskoy Culture

\begin{tabular}{|c|c|c|c|}
\hline \multirow{2}{*}{$\begin{array}{c}\text { Azov-Dnieper } \\
\text { Culture }\end{array}$} & \multirow{2}{*}{ Surskoy Culture } & \multicolumn{2}{|c|}{ CalBC } \\
\cline { 3 - 4 } & & Old dates & $\begin{array}{c}\text { Dates adjusted for the } \\
\text { reservoir effect }\end{array}$ \\
\hline & Period 1 & $6300 / 6200-5900$ & $6300 / 6200-5900$ \\
\hline & Period 2a & $5900-5750$ & $5900-5750$ \\
\hline Period 1a & Period 2b & $5750-5200$ & $5750-4900$ \\
\hline Period 1b & Period 3 & $5200-4750$ & $4900-4700$ \\
\hline
\end{tabular}


5850 calBC. Previously, the Mamaj Gora cemetery was synchronized with Chapaevka (Kotova 2003). However, a correction of the age of Mamay Gora showed that this cemetery is younger (5440-5150 calBC) and refers to period 1B of the Azov-Dnieper Culture, together with the Vovnigi 2 and Vasilievka 5 cemeteries. Sites with ceramics ornamented with comb prints and having a collar-shaped rim are included in period $1 \mathrm{~B}$. This period was previously dated at about 5750-5300/5200 calBC; presently, however, its end should be determined, by dating of reddeer teeth from Vovnigi 2, to be about 4900 calBC. Likewise, the second period of the Azov-Dnieper Culture should be dated around 4900-4700 calBC.

The second period of the Surskoy Culture was previously synchronized with the first period of the Azov-Dnieper Culture and had only one date based on animal bone from the Kizlevy 5 site (Ki-7999, 6740 \pm 90 BP). Taking into account the reservoir effect and the new dates from reddeer teeth from Neolithic cemeteries, the dates for Strilcha Skelya (Ki-8174, $6290 \pm 65$ BP) and Kamyana Mohila 1 (Ki-4025, 6376 \pm 60 BP; Ki-4024, 6180 \pm 90 BP; Ki$4023,6120 \pm 80 \mathrm{BP}$ ) should be considered as dates for the layers of the second period of the Surskoy Culture. Previously, they were correlated with the overlying layers of the late Azov-Dnieper Culture.

It was necessary to revise the chronological position of some Surskoy cemeteries (Vovnigi 3, Vovnigi 1, the first stage of Vilnyanka, and the first and second stages of Yasinovatka 1). The time frame of their existence narrowed to 5350-4950 calBC. Formerly, they were associated with the youngest sites of the Surskoy Culture (Vovnigi, right- and left-bank sites), which have pottery including elements of the second period of the Azov-Dnieper Culture (Kotova 2010; Kotova 2015). However, in connection with the rectification of the age of the Azov-Dnieper sites, the Surskoy sites of the third period should be dated at about 4900-4800 calBC. As a result, we are forced to synchronize the above-listed Surskoy cemeteries with the sites of the second period of the Surskoy Culture; thus, only the large-pit burials of the second stage of Vilnyanka (which is the influence of the late Azov-Dnieper Culture) and the burials in individual pits that overlapped them (third stage) refer to the third period of the Surskoy Culture.

The emerging picture shows a very long existence of monuments of the second period of the Surskoy Culture (5900-5000 calBC). They are synchronous with the monuments of periods $1 \mathrm{~A}$ and $1 \mathrm{~B}$ of the Azov-Dnieper Culture. It cannot be excluded that, in the future, new sites will be discovered that will allow a division of Surskoy sites of the sixth millennium calBC into at least two chronological groups.

\section{Acknowledgment}

This article has been prepared in the framework of the Swiss-Ukrainian project "Responses of vegetation and human society to climatic changes in Ukraine", carried out with financial support from the Swiss National Science Foundation (IZ73Zo-152732). 


\section{References}

Bodyanskiy A. V. 1959. Neolitichniy mogilnik bilya Nenasitietskogo poroga. Arkheologiya 5, 163-172. Bodyanskiy A. V. and Kotova N. S. 1994. Vovnigskiy 2 pozdneneoliticheskiy mogilnik. In Arkheologichni pamyatki ta istoriya starodavnogo peselennya Ukrainy 1. Lutsk: Vezha, 98-110.

Borić D., French C. and Dimitrijević V. 2008. Vlasac revisited: formation processes, stratigraphy and dating. Documenta Praehictorica 35, 261-288.

Chernykh Ye. N. 1966. Perviye spektral'niye issledovaniya medi dnepro-donetskoy kul'tury. Kratkiye soobshcheniya Instituta arkheologii AN SSSR, 106, 66-68.

Danilenko V. N. 1974. Eneolit Ukrainy: etnoistoricheskoe issledovanie. Kiev: Naukova Dumka.

Danilenko V. N. 1986. Kamyana Mohyla. Kiev: Naukova Dumka.

Kotova N. S. 1994. Mariupoloskaya kulturno-istoricheskaya oblast'. In Arkheologichni pamyatki ta istoriya starodavnogo naselennya Ukrainy 1. Kovel: Vezha, 1-143.

Kotova N. S. 2003. Neolithization in Ukraine (= British Archaeological Reports. International Series 1109). Oxford: Archaeopress.

Kotova N. S. 2010. Chronology and periodization of the Surskaja Neolithic culture. Studia Archaeologica et Mediaevalia 11, 67-90.

Kotova N. S. 2015. Drevneyshaya keramika Ukrainy. Kiyev, Kharkov: Maydan.

Kotova N. S. and Kravchenko S. N. 1992. Noviye neoliticheskiye mogilniki v Nadporozhie. In Neoliticheskiye pamyatniki Stepno Ukrainy. Kiev: Institut Arkheologii Akademii Nauk Ukrainy, 21-26.

Kotova N. S. and Tuboltsev O. V. 1992. Pozdniaya surskaya kul'tura i yeye okruzheniye. Drevnosti Stepnogo Prichernomor'ya i Kryma 3, 8-23.

Kotova N. and Tuboltsev O. 2013. The Neolithic site Kizlevy 5 in the Dnieper rapids region (Ukraine) (= Atti Della Societá per La Preistoria e Protostoria Della Regione Friuli-Venezia Giulia 18, 2010-211). Trieste: Museo Civico di Storia Naturale, 33-52.

Kotova N., Tuboltsev O., Kiosak D., Spitsyna L., Makhortykh S., Tinner W., Nielsen E. H. and Dzhos V. 2017. Preliminary results of excavations at the multilayer Kamyana Mohila 1 site (2011-2012). In S. Makhortykh, A. de Capitani (eds.), Archaeology and palaeoecology of the Ukrainian steppe. Kyiv: Maidan.

Lillie M. C. and Richards M. 2000. Stable isotope analysis and dental evidence of diet at the Mesolithic-Neolithic transition in Ukraine. Journal of Archaeological Science 27, 965-972.

Lillie M., Budd Ch., Potekhina I. and Hedges R. 2009. The radiocarbon reservoir effect: new evidence from the cemeteries of the middle and lower Dnieper basin, Ukraine. Journal of Archaeological Science 36, 256-264

Lillie M., Budd Ch. and Potekhina I. 2011. Stable isotope analysis of prehistoric populations from the cemeteries of the middle and lower Dnieper Basin, Ukraine. Journal of Archaeological Science $38,57-68$.

Lillie M., Henderson R., Budd Ch. and Potekhina I. 2016. Factors influencing the Radiocarbon Dating of Human Skeletal Remains from the Dnieper River System: Archaeological and Stable Iso- 
tope Evidence of Diet from the Epipaleolithic to Eneolithic Periods. Radiocarbon 58(4), 741-753.

Rudinskiy M. Ya. 1956. Pershiy Vovnizkiy pizdnoneolitichniy mogilnik. AP Arkheologichni pam'yatki URSR 6, 152-161.

Telegin D. Ya. 1990. Novyye raskopki poseleniya Kamennaya Mogila v Priazov'ye. In Problemy arkheologii Severnogo Prichernomor'ya (k 10o-letiyu osnovaniya Khersonskogo muzeya drevnostey). Tezisy dokladov yubileynoy konferentsii. Kherson, 31-33.

Telegin D. Ya. and Potekhina I. 1987. Neolithic cemeteries and population in the Dnieper Basin (= British Archaeological Reports. International Series 383). Oxford: Archaeopress.

Telegin D. Ya., Lillie M. C., Potekhina I. D. and Kovaliukh M. M. 2003. Settlement and economy in Neolithic Ukraine: a new chronology. Antiquity 77 (279), 456-470.

Toscev G. N. 2005. Die neolithische Nekropole Mamaj-Gora im unternen Dneprgebiet. Godisnjak 34, 21-39. 